Artikel Penelitian

\title{
Uji Aktivitas Antibakteri Rambut Jagung Manis (Zea mays ssaccarata Strurt) terhadap Bakteri Staphylococcus aureus dan Escherichia coli
}

\author{
Akyunul Jannah*, Dhinarty Umi Rachmawaty, Anik Maunatin \\ Jurusan Kimia, Fakultas Sains dan Teknologi, Universitas Islam Negeri Maulana Malik Ibrahim Malang, Malang
}

\section{INFO ARTIKEL}

Sejarah artikel:

Revisi 08 September 2017

Diterima 20 Oktober 2017

Tersedia online 14 Desember 2017
*Penulis korespondensi

Email:

akyunul_jannah2008@yahoo.com

\section{ABSTRAK}

Sweet corn silk contains active compounds which act as an antibacterial. In this study, sweet corn silk extract was determined antibacterial activity in various solvents, Minimum Inhibitory Concentration (MIC) and Minimum Bactericidal Concentration (MBC). Extraction of sweet corn silk was conducted by maceration method. Antibacterial activity was tested with the disc diffusion method, then followed by MIC and MBC tests at $250 ; 125 ; 62.5 ; 31.25$ and $15.625 \mathrm{mg} / \mathrm{mL}$ using liquid dilution method and drop plate method. The result showed that its inhibition zone against bacteria $E$. coli and $S$. aureus was 19.3 and $13 \mathrm{~mm}$ for ethanol extract, 9.3 and $12.3 \mathrm{~mm}$ for ethyl acetate extract, while the petroleum ether extract is also inhibited E.coli with its inhibition zone $2.67 \mathrm{~mm}$ but has no antibacterial activity on S. aureus. Ethanol extract had the MIC to E. coli and $S$. aureus was $125 \mathrm{mg} / \mathrm{mL}$, while MBC was $250 \mathrm{mg} / \mathrm{mL}$.

Keywords: sweet corn silk, antibacterial, MIC, MBC, S. aureus, E. coli

Rambut jagung manis memiliki kandungan senyawa aktif yang berfungsi sebagai antibakteri. Pada penelitian ini dilakukan uji aktivitas antibakteri ekstrak rambut jagung manis dengan variasi pelarut, penentuan Konsentrasi Hambat Minimum (KHM) dan Konsentrasi Bunuh Minimum (KBM). Ekstraksi rambut jagung manis dilakukan dengan metode maserasi. Uji aktivitas antibakteri dilakukan dengan metode difusi cakram, dilanjutkan dengan pengujian KHM dan KBM pada konsentrasi 250; 125; 62,5; 31,25 dan $15,625 \mathrm{mg} / \mathrm{mL}$ dengan menggunakan metode dilusi cair dan drop plate. Hasil penelitian diperoleh diameter zona hambat terhadap bakteri $E$. coli dan $S$. aureus untuk ekstrak etanol 19,3 $\mathrm{mm}$ dan $13 \mathrm{~mm}$; ekstrak etil asetat $9,3 \mathrm{~mm}$ dan $12,3 \mathrm{~mm}$; ekstrak petroleum eter 2,67 mm, dan tidak dapat menghambat pertumbuhan bakteri $S$. aureus. KHM dan KBM ekstrak etanol masing-masing pada konsentrasi 125 dan $250 \mathrm{mg} / \mathrm{mL}$.

Kata kunci: rambut jagung manis, antibakteri, KHM, KBM, S. aureus, $E$. coli 


\section{Pendahuluan}

Jagung merupakan tanaman yang paling produktif yang tumbuh baik di negara tropis maupun subtropis. Selain digunakan sebagai makanan pokok, masyarakat di beberapa daerah di Indonesia memanfaatkan jagung sebagai pakan ternak (Yusuf, 2009). Jagung manis merupakan salah satu jenis jagung yang banyak dibudidayakan sehingga dihasilkan rambut jagung yang melimpah (Setiawan, 2003). Rambut jagung merupakan salah satu limbah setelah tanaman jagung dipanen.

Beberapa penelitian menyebutkan bahwa rambut jagung mengandung berbagai metabolit sekunder. Wirasutisna, Fidrianny, \& Rahmayani (2012) menyatakan bahwa serbuk rambut jagung mengandung flavonoid dan steroid/triterpenoid. Bhaigyabati, Kirithika, Ramya, \& Usha, (2011) menyatakan bahwa metabolit sekunder rambut jagung manis yaitu antrakuinon, alkaloid, flavonoid, glikosida, saponin, steroid, tanin, terpenoid, dan fenol. Solihah, Wan Rosli, \& Nurhanan (2012) menambahkan bahwa ekstrak air dan metanol rambut jagung mengandung fenol, flavonoid, tanin, alkaloid, terpenoid, saponin dan glikosida.

Rambut jagung dapat dimanfaatkan di bidang kesehatan, diantaranya sebagai antioksidan (Guo, Liu, Han, \& Liu, 2009), memiliki efek diuretik (Velazquez, Xavier, Batista, \& de Castro-Chaves, 2005), menurunkan hiperglikemik (Farsi et al., 2008), antidepresi (Ebrahimzadeh, Pourmorad, \& Hafezi, 2008) dan antidiabetes (Feng, Wang, Tao, \& Zhou, 2011). Feng, Wang, Tao, Zhou, \& Zhong (2012) menyatakan bahwa ekstrak air dan ekstrak etanol rambut jagung memiliki aktivitas antibakteri. Pada penelitian ini dilakukan ekstraksi dengan variasi pelarut menggunakan etanol, etil asetat dan petroleum eter. Ketiga pelarut tersebut memiliki tingkat kepolaran yang berbeda. Ekstrak ketiga diuji kemampuan antibakteri terhadap Staphylococcus aureus dan Echerichia coli.

Kemampuan aktivitas antibakteri dilakukan menggunakan uji Konsentrasi Hambat Minimum (KHM) dan Konsentrasi Bunuh Minimum (KBM). KHM bertujuan untuk mengetahui derajat resistensi, sedangkan KBM untuk mengetahui kemampuan menghambat atau membunuh bakteri. Feng, et al. (2012) menyatakan uji KHM dan KBM ekstrak etanol rambut jagung memiliki aktivitas antibakteri terhadap $E$. coli pada konsentrasi 62,5 $\mathrm{mg} / \mathrm{mL}, B$. cereus pada konsentrasi $15,625 \mathrm{mg} / \mathrm{mL}$, $S$. aureus, $P$. aeruginosa, dan $C$. albicans pada konsentrasi $31,25 \mathrm{mg} / \mathrm{mL}$.

\section{Bahan dan metode}

\subsection{Bahan}

Sampel yang digunakan pada penelitian ini adalah rambut jagung manis. Sampel diekstrak dengan etanol 96\% (Merck), etil asetat (Merck), dan petroleum eter (Merck). Uji antibakteri dilakukan terhadap $S$. aureus dan E. coli (koleksi UGM). Media untuk pertumbuhan bakteri yaitu Nutrien Agar (Merck), Nutrien Broth (Himedia), dan EMB (Eosin Methylene Blue). Bahan lain yang digunakan meliputi kloramfenikol, reagen Mayer, reagen Dragendorff, reagen Wargen, serbuk Mg, metanol (Merck), $\mathrm{HCl}$ (LIPI), kloroform (Merck), asam asetat (Merck), $\mathrm{FeCl}_{3}$ (Merck), $\mathrm{NaCl}$ (Himedia), gelatin dan $\mathrm{H}_{2} \mathrm{SO}_{4}$ (LIPI).

\subsection{Penentuan kadar air}

Rambut jagung manis sebanyak 2 gram dimasukkan ke dalam cawan yang beratnya konstan. Kemudian, dioven dengan suhu 100$105^{\circ} \mathrm{C}$ selama 15 menit dan dimasukkan dalam desikator selama 10 menit, selanjutnya dilakukan penimbangan. Perlakuan tersebut dilakukan berulang hingga diperoleh berat sampel yang konstan. Kadar air dihitung menggunakan Persamaan 1.

Kadar air $=\frac{(b-c)}{b-a} \times 100 \%$

Dimana a adalah bobot cawan kosong, $b$ adalah bobot sampel dan cawan sebelum dipanaskan, dan c adalah bobot cawan dan sampel setelah dipanaskan.

\subsection{Ekstraksi rambut jagung manis}

Serbuk rambut jagung sebanyak 75 gram dibagi dalam 3 bagian dan masing-masing direndam pada etanol, etil asetat dan petroleum eter selama $3 \times 24$ jam. Perbandingan sampel dengan pelarut adalah 1:5 (b/v). Setiap 24 jam, ekstrak disaring dan residunya dimaserasi kembali menggunakan pelarut baru. Maserasi dilakukan pada suhu ruang dan sesekali diaduk. Filtrat hasil maserasi digabungkan kemudian dipekatkan. Suhu yang digunakan pada rotary evaporator vacuum untuk ekstrak etanol dan etil asetat adalah $60^{\circ} \mathrm{C}$ sedangkan suhu untuk ekstrak petroleum eter adalah $30^{\circ} \mathrm{C}$. Ekstrak pekat yang dihasilkan kemudian ditimbang (Ren, Liu, \& Ding, 2009) dan dihitung rendemennya menggunakan Persamaan 2.

Rendemen $=\frac{\text { berat ekstrak kasar }}{\text { berat sampel awal }} \times 100 \%$ 


\subsection{Perhitungan jumlah sel bakteri}

Tabung reaksi sebanyak 7 buah diisi dengan $\mathrm{NaCl} 0,9 \%$ steril sebanyak $9 \mathrm{~mL}$. Inokulum bakteri $S$. aureus dan $E$. coli dalam media NB diambil sebanyak $1 \mathrm{~mL}$ dan dimasukkan ke dalam tabung pertama lalu dihomogenisasi dan dihitung sebagai pengenceran pertama $\left(10^{-1}\right)$. Prosedur tersebut diulangi hingga diperoleh pengenceran $10^{-7}$. Penghitungan jumlah sel bakteri dilakukan dengan metode total plate count (TPC). Masing-masing pengenceran diambil sebanyak $1 \mathrm{~mL}$ dan dimasukkan dalam cawan petri yang berisi media NA. Cawan petri diinkubasi selama 24 jam pada suhu $37^{\circ} \mathrm{C}$. Perhitungan dilakukan dengan cara memilih cawan petri yang mempunyai koloni antara 30-300. Jika perbandingan antara kedua pengenceran $<2$, maka nilai yang diambil adalah rata-rata dari kedua nilai tersebut dengan memperhatikan nilai pengencerannya. Jika perbandingannya $>2$, maka diambil yang terbesar atau yang terkecil (Harmita \& Radji, 2008). Penentuan jumlah bakteri menggunakan Persamaan 3.

Jumlah bakteri $=$ jumlah koloni $x \frac{1}{f p} \mathrm{cfu}$

Dimana $\mathrm{fp}$ adalah faktor pengenceran dan cfu adalah colony forming unit.

\subsection{Uji aktivitas antibakteri}

Media NA dituangkan dalam cawan petri dan dicampurkan masing-masing dengan $0,1 \mathrm{~mL}$ larutan bakteri $S$. aureus dan E. coli. Setelah itu, dihomogenkan dan dibiarkan hingga memadat. Kertas cakram dengan diameter $5 \mathrm{~mm}$ direndam pada ekstrak rambut jagung manisl. Kertas cakram diletakkan pada permukaan media menggunakan pinset steril. Cawan petri diinkubasi pada suhu $37^{\circ} \mathrm{C}$ selama 24 jam hingga muncul daerah hambat. Uji aktivitas antibakteri pada masingmasing pelarut dilakukan secara duplo dan diulang sebanyak 3 kali. Zona hambat diukur dengan menggunakan penggaris untuk menentukan aktivitas bakteri (Mulyadi, Wuryanti, \& Sarjono, 2013). Luas zona hambat ditentukan dengan Persamaan 4.

Zona hambat $=\mathrm{x}-\mathrm{y}$

Dimana, $x=$ zona keseluruhan dan $y=$ diameter cakram.

\subsection{Uji fitokimia ekstrak rambut jagung manis}

\subsubsection{Uji alkaloid}

Ekstrak rambut jagung dimasukkan ke dalam tabung reaksi kemudian ditambahkan $\mathrm{HCl} 2 \%$ sebanyak $0,5 \mathrm{~mL}$. Larutan dibagi menjadi dua tabung, dimana tabung I ditambahkan $0,5 \mathrm{~mL}$ reagen Dragendorff, sedangkan tabung II ditambahkan 2-3 tetes reagen Mayer. Jika tabung I terbentuk endapan berwarna jingga dan pada tabung II terbentuk endapan berwarna kekuningkuningan, menunjukkan adanya alkaloid (Indrayani, Soedjipto, \& Sihasale, 2006).

\subsubsection{Uji flavonoid}

Ekstrak rambut jagung dimasukkan ke dalam tabung reaksi kemudian dilarutkan dalam 1-2 mL metanol panas $50 \%$. Setelah itu, ditambahkan serbuk $\mathrm{Mg}$ dan $0,5 \mathrm{~mL} \mathrm{HCl}$ pekat. Adanya flavonoid ditunjukkan dengan terbentuknya larutan berwarna merah atau jingga (Indrayani,et al., 2006).

\subsubsection{Uji Steroid dan triterpenoid}

Ekstrak rambut jagung dimasukkan ke dalam tabung reaksi, dilarutkan dalam $0,5 \mathrm{~mL}$ kloroform kemudian ditambahkan $0,5 \mathrm{~mL}$ asam asetat anhidrat. Kemudian, sampel ditambah 1-2 mL $\mathrm{H}_{2} \mathrm{SO}_{4}$ pekat memalui dinding tabung tersebut. Apabila terbentuk warna hijau atau biru, maka ekstrak positif mengandung steroid, sedangkan apabila terbentuk warna ungu-merah, maka ekstrak positif mengandung triterpenoid (Indrayani, et. al., 2006).

\subsubsection{Uji tanin}

Pengujian tanin dengan $\mathrm{FeCl}_{3}$ dilakukan dengan memasukkan ekstrak rambut jagung manis ke dalam tabung reaksi. Setelah itu, ditambahkan 2-3 tetes larutan $\mathrm{FeCl}_{3} 1 \%$. Jika bahan mengandung tanin maka akan dihasilkan larutan berwarna hijau kehitaman atau biru tua. Pengujian tanin dengan gelatin dilakukan dengan memasukkan ekstrak rambut jagung manis ke dalam tabung reaksi. Kemudian, ditambahkan larutan gelatin. Apabila terbentuk endapan putih maka bahan tersebut mengandung tanin (Utami, 2014).

\subsubsection{Uji saponin}

Ekstrak rambut jagung manis sebanyak $1 \mathrm{mg}$ ditambahkan aquades $10 \mathrm{~mL}$ dan dikocok selama 30 menit sampai muncul busa. Tabung reaksi 
diletakkan dalam posisi tegak selama 30 menit. Apabila masih terdapat busa, maka kemungkinan mengandung saponin. Untuk memastikan bahwa busa yang terbentuk berasal dari saponin maka diteteskan larutan asam sebanyak 3 tetes, bila busa stabil maka dipastikan terdapat saponin (Sari, Rita, \& Puspawati, 2015).

\subsubsection{Uji fenol}

Ekstrak rambut jagung sebanyak $30 \mathrm{mg}$ ditambahkan 10 tetes $\mathrm{FeCl}_{3} 1 \%$. Ekstrak positif mengandung fenol apabila menghasilkan warna hijau, merah, ungu, biru atau hitam pekat (Harborne, 1987).

\subsection{Uji Konsentrasi Hambat Minimum (KHM)}

Uji KHM dilakukan dengan metode dilusi tabung atau pengenceran yaitu penanaman bakteri pada media NB pada tabung reaksi. Pada penelitian ini, disiapkan 30 tabung reaksi untuk percobaan dan 3 tabung reaksi untuk kontrol. Tabung reaksi sebanyak 15 buah reaksi diisi dengan $1 \mathrm{~mL}$ NB dan $1 \mathrm{~mL}$ suspensi bakteri $S$. aureus dan $E$. coli pada kontrol positif dan pada kontrol negatif berisi 1 gram ekstrak sampel dan $1 \mathrm{~mL}$ NB.

Lima belas tabung reaksi yang lain diisi dengan $9 \mathrm{~mL}$ NB steril dan ditambahkan $0,5 \mathrm{~mL}$ suspensi bakteri $S$. aureus dan $E$. coli dan $0,5 \mathrm{~mL}$ ekstrak rambut jagung yang telah diencerkan pada DMSO $10 \%$ dengan konsentrasi 250; 125; 62,5; 31,25; 15 , $625 \mathrm{mg} / \mathrm{mL}$. Masing-masing konsentrasi dibuat pada 3 tabung untuk tiga kali pengulangan. Sebanyak $3 \mathrm{~mL}$ sampel diambil secara aseptis untuk dibaca absorbansinya pada panjang gelombang $600 \mathrm{~nm}$. Sampel diinkubasi pada suhu $37^{\circ} \mathrm{C}$ selama 24 jam, dihomogenkan dan diukur nilai absorbansinya kembali. Perhitungan nilai KHM menggunakan Persamaan 5.

$\mathrm{KHM}=\mathrm{OD}$ setelah $-\mathrm{OD}$ sebelum inkubasi

dimana KHM adalah konsentrasi hambat minimum dan OD adalah optical density. Konsentrasi terendah yang dapat menghambat bakteri ditunjukkan dengan tidak adanya kekeruhan setelah diinkubasi (OD $\leq$ 0) (Rahmawati, 2014).

\subsection{Uji Konsentrasi Bunuh Minimum (KBM)}

Penentuan KBM dilakukan pada konsentrasi yang positif KHM. Penentuan KBM dilakukan dengan metode Drop Plate Mills Mesra. Sampel diambil $10 \mu \mathrm{L}$ untuk tiap konsentrasi kemudian diteteskan pada media NA untuk bakteri $S$. aureus dan media EMB untuk bakteri E. coli. Setelah itu, didiamkan selama 15-20 menit sampai mengering dan diinkubasi dalam inkubator pada suhu $37^{\circ} \mathrm{C}$ selama 6 jam. Perhitungan jumlah koloni bakteri dilakukan dengan prinsip satu sel bakteri hidup bila dibiakkan pada media padat akan tumbuh menjadi 1 koloni bakteri. Perhitungannya bersinggungan dianggap 2 koloni. Satuan yang dipakai adalah CFU (Colony Forming Unit)/mL cairan (suspensi) (Siregar, 2011).

\section{Hasil dan pembahasan}

\subsection{Uji kadar air}

Analisis kadar air untuk mengetahui konsentrasi air pada bahan sampel. Farmakope Indonesia menyatakan bahwa kadar air pada suatu sampel bahan obat tidak boleh melebihi $10 \%$ (Departemen Kesehatan RI, 1995). Hasil pengukuran kadar air yang diperoleh yaitu sebesar $8,74 \%$ sehingga memenuhi persyaratan Farmakope Indonesia.

\subsection{Ekstraksi rambut jagung manis}

Rendemen ekstrak rambut jagung manis hasil ekstraksi dari pelarut etanol, etil asetat dan petroleum eter ditunjukkan pada Tabel 1. Berdasarkan Tabel 1 dapat diketahui bahwa hasil ekstraksi dengan pelarut etanol menghasilkan rendemen paling tinggi. Hal ini disebabkan senyawa pada rambut jagung manis lebih banyak bersifat polar.

\section{Tabel 1}

Rendemen ekstrak rambut jagung manis.

\begin{tabular}{lc}
\multicolumn{1}{c}{ Jenis pelarut } & Rendemen (\%) \\
\hline Etanol & 8,894 \\
Etil asetat & 3,005 \\
Petroleum eter & 0,652 \\
\hline
\end{tabular}

\subsection{Uji fitokimia ekstrak rambut jagung manis}

Uji fitokimia bertujuan untuk mengetahui kandungan senyawa aktif/metabolit sekunder dalam sampel. Hasil uji fitokimia ekstrak rambut jagung manis secara kualitatif ditunjukkan pada Tabel 2. Berdasarkan Tabel 2 menunjukkan bahwa ekstrak etanol mengandung lebih banyak senyawa aktif dibandingkan ekstrak etil asetat dan petroleum eter. 


\subsection{Uji aktivitas antibakteri}

Kemampuan antibakteri ekstrak rambut jagung manis dilakukan terhadap bakteri patogen E. coli (Gram negatif) dan S. aureus (Gram positif). Aktivitas antibakteri ditentukan dengan mengukur zona hambat yang terbentuk di sekitar kertas cakram. Ekstrak yang digunakan untuk uji aktivitas antibakteri memiliki konsentrasi 100\% (b/v) dengan DMSO sebagai pengencer. Kontrol negatif yang digunakan adalah DMSO 100\%, sedangkan kontrol positif yang digunakan adalah kloramfenikol. Diameter zona hambat yang dihasilkan dari uji aktivitas antibakteri disajikan dalam Tabel 3 . Ekstrak etanol memiliki aktivitas paling tinggi dibandingkan ekstrak yang lain. Aktivitas penghambatan ekstrak etanol dan etil asetat dapat dikategorikan kuat sedangkan aktivitas penghambatan ekstrak petroleum eter dikategorikan lemah.

\section{Tabel 2}

Uji fitokimia ekstrak rambut jagung manis

\begin{tabular}{lccc}
\hline \multicolumn{1}{c}{$\begin{array}{c}\text { Golongan } \\
\text { senyawa }\end{array}$} & \multicolumn{3}{c}{ Jenis pelarut } \\
\cline { 2 - 4 } & Etanol & $\begin{array}{c}\text { Etil } \\
\text { asetat }\end{array}$ & $\begin{array}{c}\text { Petroleum } \\
\text { eter }\end{array}$ \\
\hline Alkaloid & & & - \\
- Reagen Mayer & + & - & - \\
- Reagen & + & - & + \\
$\quad$ dragendorf & + & - & + \\
Flavonoid & + & + & \\
Steroid/Triterpenoid & + & & - \\
Tanin & + & + & - \\
- FeCl & + & - & - \\
- Gelatin & + & - & + \\
Saponin & + & + & \\
Fenol & & &
\end{tabular}

\section{Tabel 3}

Rata-rata diameter zona hambat ekstrak rambut jagung manis

\begin{tabular}{lcc}
\hline \multirow{2}{*}{ Jenis ekstrak } & \multicolumn{2}{c}{ Rata-rata zona hambat $(\mathbf{m m})$} \\
\cline { 2 - 3 } & E. coli & S. aureus \\
\hline Etanol & 19,3 & 13,0 \\
Etil asetat & 9,30 & 12,3 \\
Petroleum eter & 2,67 & 0 \\
Kontrol positif & 26,7 & 38,0 \\
\hline
\end{tabular}

\subsection{Uji KHM dan KBM}

Uji KHM dan KBM dilakukan pada ekstrak etanol rambut jagung manis. Hal ini dikarenakan ekstrak etanol memiliki rendemen yang tinggi dan aktivitas antibakteri yang besar. Uji KHM dilakukan pada konsentrasi 250; 125; 62,5; 31,25; 15,625 $\mathrm{mg} / \mathrm{mL}$. Kontrol positif berupa campuran suspensi bakteri dalam media NB, sedangkan kontrol negatif berupa campuran ekstrak rambut jagung dan media NB steril. Berdasarkan uji KHM diketahui bahwa ekstrak etanol rambut jagung manis yang telah dilakukan didapatkan selisih nilai absorbansi yang disajikan pada Tabel 4 .

\section{Tabel 4}

Nilai absorbansi KHM ekstrak rambut jagung manis

\begin{tabular}{ccc}
\hline \multirow{2}{*}{$\begin{array}{c}\text { Konsentrasi } \\
(\mathbf{m g} / \mathrm{mL})\end{array}$} & \multicolumn{2}{c}{ Rata-rata selisih absorbansi } \\
\cline { 2 - 3 } & S. aureus & E. coli \\
\hline 15,625 & 0,4036 & 0,1472 \\
31,25 & 0,3443 & 0,1192 \\
62,5 & 0,1890 & 0,0787 \\
125 & $-0,2668$ & $-0,1192$ \\
250 & $-0,3215$ & $-0,3740$ \\
Kontrol Positif & 0,8684 & 0,6449 \\
Kontrol Negatif & \multicolumn{2}{c}{0,0447} \\
\hline
\end{tabular}

Berdasarkan pada Tabel 4 diketahui campuran ekstrak etanol rambut jagung manis dan suspensi bakteri yang menunjukkan hasil positif KHM yaitu pada konsentasi $125 \mathrm{mg} / \mathrm{mL}$ dan 250 $\mathrm{mg} / \mathrm{mL}$. Kedua konsentrasi tersebut ditanam pada media padat masing-masing bakteri untuk mengetahui KBM. Hasil perhitungan jumlah koloni bakteri pada uji KBM ditampilkan pada Tabel 5 . KBM ekstrak etanol rambut jagung manis terhadap bakteri $E$. coli dan $S$. aureus terdapat pada konsentrasi sampel sebesar $250 \mathrm{mg} / \mathrm{mL}$.

\section{Tabel 5}

Jumlah koloni bakteri pada uji KBM

\begin{tabular}{ccccc}
\hline $\begin{array}{c}\text { Jenis } \\
\text { bakteri }\end{array}$ & $\begin{array}{c}\text { Konsentrasi } \\
\text { ekstrak } \\
\text { (mg/mL) }\end{array}$ & \multicolumn{3}{c}{$\begin{array}{c}\text { Jumlah koloni } \\
\text { (cfu/mL) }\end{array}$} \\
\hline \multirow{2}{*}{ E. coli } & 250 & I & II & III \\
\hline \multirow{2}{*}{ S. aureus } & 125 & 103 & 0 & 0 \\
& 250 & 0 & 0 & 64 \\
& 125 & $>300$ & $>300$ & $>300$ \\
\hline
\end{tabular}

\section{Kesimpulan}

Ekstrak rambut jagung manis dapat menghambat pertumbuhan bakteri $E$. coli dan $S$. aureus. Diameter zona hambat ekstrak etanol terhadap $E$. coli dan $S$. aureus masing-masing sebesar 19,3 dan $13 \mathrm{~mm}$. Ekstrak etil asetat memberikan zona hambat sebesar $9,3 \mathrm{~mm}$ untuk $E$. coli dan 12,3 untuk $S$. aureus. Ekstrak petroleum 
eter dapat menghambat pertumbuhan $E$. coli sebesar 2,67 mm, tapi tidak dapat menghambat pertumbuhan $S$. aureus. Ekstrak etanol merupakan ekstrak terbaik dengan nilai $\mathrm{KHM} 125 \mathrm{mg} / \mathrm{mL}$ dan nilai KBM $250 \mathrm{mg} / \mathrm{mL}$.

\section{Daftar pustaka}

Bhaigyabati, T., Kirithika, T., Ramya, J., \& Usha, K. (2011). Phytochemical constituents and antioxidant activity of various extracts of corn silk (Zea mays. L). Research Journal of Pharmaceutical, Biological and Chemical Sciences, 2(4), 986-993.

Departemen Kesehatan RI. (1995). Farmakope Indonesia (IV). Departemen Kesehatan RI. Jakarta.

Ebrahimzadeh, M. A., Pourmorad, F., \& Hafezi, S. (2008). Antioxidant activities of Iranian corn silk. Turkish Journal of Biology, 32(1), 43-49.

Farsi, D. A., Harris, C. S., Reid, L., Bennett, S. A., Haddad, P. S., Martineau, L. C., \& Arnason, J. T. (2008). Inhibition of non-enzymatic glycation by silk extracts from a Mexican land race and modern inbred lines of maize (Zea mays). Phytotherapy Research, 22(1), 108112.

Feng, X., Wang, L., Tao, M. L., \& Zhou, Q. (2011). Studies on antimicrobial activity of aqueous extract of maize silk. Applied Mechanics and Materials, 140(2), 426-430.

Feng, X., Wang, L., Tao, M. L., Zhou, Q., \& Zhong, Z.H. (2012). Studies on antimicrobial activity of ethanolic extract of maize silk. African Journal of Microbiology Research, 6(2), 335-338.

Guo, J., Liu, T., Han, L., \& Liu, Y. (2009). The effects of corn silk on glycaemic metabolism. Nutrition \& Metabolism, 6, 47.

Harborne, J. B. (1987). Metode fitokimia, penuntun cara modern menganalisis tumbuhan. ITB Press. Bandung.

Harmita, \& Radji, M. (2008). Kepekaan terhadap antibiotik. In Buku Ajar Analisis Hayati, Ed.3. EGC. Jakarta.

Indrayani, L., Soedjipto, H., \& Sihasale, L. (2006). Skrining fitokimia dan uji toksisitas ekstrak daun pecut kuda (Stachytarpheta jamaicensis L. Vahl.) terhadap larva udang Artemia salina Leach. Berkala Penelitian Hayati, 12, 57-61.

Mulyadi, M., Wuryanti., \& Sarjono, P. R. (2013). Konsentrasi hambat minimum (KHM) kadar sampel alang-alang (Imperata cylindrica) dalam etanol melalui metode difusi cakram. Chem Info, 1(1), 35-42.

Rahmawati, R. (2014). Uji aktivitas antibakteri ekstrak etanol daun sisik naga (Drymoglossum pilosselloid (L.) Pesl) dan binahong (Anredera cordifolia (Ten.) Steenis) terhadap bakteri Streptococcuus mutans. Skripsi. Universitas Islam Negeri Maulana Malik Ibrahim Malang. Malang.

Ren, S. C., Liu, Z. L., \& Ding, X. L. (2009). Isolation and identification of two novel flavone glycosides from corn silk (Stigma maydis). Journal of Medicinal Plants Research, 3(12), 1009-1015.

Sari, P. P., Rita, W. S., \& Puspawati, N. M. (2015). Identifikasi dan uji aktivitas senyawa tanin dari ekstrak daun trembesi (Samanea saman (Jacq.) Merr) sebagai antibakteri Escherichia coli. Jurnal Kimia, 9(1), 27-34.

Setiawan, A. I. (2003). Penghijauan lahan kritis. Penebar Swadaya. Jakarta.

Siregar, B. (2011). Daya antibakteri ekstrak buah mahkota dewa (Phaleria macrocarpa [Scheff.] boerl) terhadap pertumbuhan Streptococcus mutans (in vitro). Skripsi. Universitas Sumatera Utara.

Solihah, M. A., Wan Rosli, W. I., \& Nurhanan, A. R. (2012). Phytochemicals screening and total phenolic content of Malaysian Zea mays hair extracts. International Food Research Journal, 19(4), 1533-1538.

Utami, K. S. (2014). Uji aktivitas antibakteri fraksi etil asetat, kloroform, petroleum eter, dan nheksana hasil hidrolisis ekstrak metanol mikroalga Chlorella sp. Skripsi. Universitas Islam Negeri Maulana Malik Ibrahim Malang. Malang.

Velazquez, D. V., Xavier, H. S., Batista, J. E., \& de Castro-Chaves, C. (2005). Zea mays L. extracts modify glomerular function and potassium urinary excretion in conscious rats. Phytomedicine, 12(5), 363-369.

Wirasutisna, K. R., Fidiranny, I., \& Rahmayani, A. (2012). Telaah kandungan kimia rambut jagung (Zea mays L.). Acta Pharmaceutica Indonesia, XXXVII(1), 1-8.

Yusuf, R. P. (2009). Kajian pendapatan petani pada usaha tani jagung (Kasus di Desa Sanggalangit, Kecamatan Gerokgak, Kabupaten Buleleng). Jurnal Sosial Ekonomi Pertanian dan Agribisnis SOCA, 9(3), 263390. 